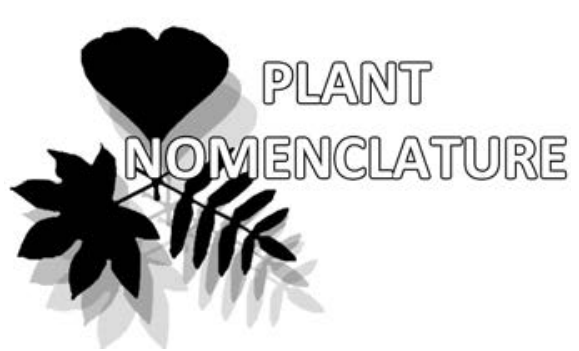

\title{
Typification of the name Nitraria komarovii (Nitrariaceae)
}

\author{
Nataliya K. Kovtonyuk*, Maria A. Tomoshevich \& Evgeniy V. Banaev
}

Nataliya K. Kovtonyuk*

e-mail: nkovtonyuk@csbg.nsc.ru

Maria A. Tomoshevich

e-mail: arysa9@mail.ru

Evgeniy V. Banaev

e-mail: alnus2005@mail.ru

Central Siberian Botanical Garden SB RAS Novosibirsk, Russia

* corresponding author

Manuscript received: 27.10.2019

Review completed: 31.10.2019

Accepted for publication: 01.11.2019

Published online: 02.11.2019

\begin{abstract}
A B S T R A C T
Nitraria komarovii, the name of a species of the Nitrariaceae family, is not typified yet. The species is known from only 3 habitats-Western (Absheron Peninsula, Azerbaijan) and Eastern (Turkmenbashi, locus classicus) coasts of the Caspian Sea and the coast of Lake Balkhash (Kazakhstan). Its economic potential may be commercially exploited, as a promising ornamental, ameliorative, food and medicinal plant of desert and saline areas. Here, a lectotype is designated for Nitraria komarovii and a historical background for typification of this name is provided.
\end{abstract}

Ke y w o r d s : lectotypification, nomenclature, digital herbarium, Central Asia, flora of Russia, Siberia, Nitraria komarovii, Zygophyllaceae

\section{P E 3 Ю M E}

Ковтонюк Н.К., Томошевич М.А., Банаев Е.В. Типификация имени Nitraria komarovii. Название вида Nitraria komarovii из семейства Nitrariaceae Ао сих пор не типифицировано. Вил известен всего из 3 местообитаний: западное (п-ов Апшерон, Азербайджан) и восточное (Туркменбаши, классическое местообитание) побережья Каспийского моря и побережье оз. Балхаш (Казахстан). Его экономический потенциал может быть коммерчески использован, как перспективное декоративное, мелиоративное, пищевое и мекарственное растение пустынных и засоленных районов. В статье Аано историческое обоснование Аля типификации и обозначен мектотип названия Nitraria komarovii.

КАючевые слова: мектотипификация, номенклатура, цифровой гербарий, Центральная Азия, флора России, Сибирь, Nitraria komarovii, Zygophyllaceae
The genus Nitraria L., described by Linnaeus (1759), includes 9 species (Bobrov 1949, Wilson 1992). Previously Nitraria was included in the family Zygophyllaceae (Bobrov 1949, Nikitin 1950), but in the last taxonomic treatment (Wilson 1992) and the most recent phylogenetic assessment (APG IV 2016) it was placed in a family of its own Nitrariaceae. Plants of the genus are common in the steppe and desert regions of Central Asia, in the mountainous regions of South Siberia, Southeastern Europe, in North Africa and in Southeast Australia. The species grow on saline desert soils and semi-deserts, on saline gypsum soils, on clay-sandy soils of the coasts and on the shores of salt lakes.

Nitraria komarovii Iljin \& Lava ex Bobrov (1946: 28) is the name of a native for the western and eastern coasts of the Caspian Sea and for Western Turkmenistan that is not typified yet. Its economic potential may be commercially exploited as a promising ornamental, ameliorative, food and medicinal plant of desert and saline areas (Banaev et al. 2015, Voronkova et al. 2017, Tomoshevich et al. 2019a).

\section{MATERIAL AND METHODS}

Our study is based on an analysis of relevant literature (Linnaeus 1759, Trautvetter 1871, Iljin 1944, Bobrov 1946, 1949, 1965, 1974, Lava 1948, Nikitin 1950, Wilson 1992). Banaev and Tomoshevich have examined living populations of Nitraria species in the field on the coasts of the Caspian
Sea, in Crimea, Tajikistan, Kazakhstan and Siberia as well as herbarium specimens stored in the NSK collections (Thiers 2019) as vouchers (NSK3000924, NSK3000925, NSK3000927, NSK3000939, NSK3000959, NSK3000986, NSK3000995). Their digital copies placed in the open access in the Digital herbarium of CSBG SB RAS (http:/ / herb.csbg.nsc.ru:8081). We have studied Nitraria herbarium specimens that belong to the original material from the Komarov Botanical institute of the Russian Academy of Sciences (LE) and other Nitraria specimens native to the flora of Russia using online herbarium databases at E, K, LINN, MW and P. The protologues, type specimens of all Nitraria species and information from POWO (2019) database were analyzed during our research.

\section{RESULTS AND DISCUSSION Historical background}

The name Nitraria komarovii was first used in Ilyin (1944: 117), but without a diagnosis in Latin: "Nitraria Komarovii Iljin et Lava, sp. nov. (typus Krasnovodsk, littora maris Caspii, 22 X 1900, leg. Freyn). Этот изящный виА с узкими Аистьями, Аегко отАичимый от Аругих виАов Nitraria исключительно связан с морским побережьем Каспия и особенно распространен в южной части." [This elegant species with narrow leaves, easily distinguishable from other species of Nitraria is solely associated with the 
coast of the Caspian Sea and is particularly common in the southern part - translated by N.K.]. According to Art. 39.1 (ICN, Turland et al. 2018) the name Nitraria komarovii was therefore not validly published. Later Bobrov (1946: 28) validated the name, Nitraria komarovii, by providing a Latin description: "Folia longiora lineari-spathulata basi longius angustata, cyma gracilior. Habitat in Turkomania occidentali et in peninsula Apscheron" and providing a direct reference to Nitraria schoberi var. polygama Trautvetter (1871: 25) that was included by Bobrov in its synonymy and based on plants collected by Radde in Krasnowodsk, Turcomania in 1870. Thus the name, Nitraria komarovii, was not explicitly proposed as a substitute for an earlier name N. schoberi var. polygama and according to Art. 6.13 of the ICN (Turland et al. 2018) "may be treated either as a replacement name or as the name of a new taxon" as "in the protologue both (a) a potential replaced synonym is cited and (b) all requirements for valid publication of the name of a new taxon are independently met. Decision on the status of such is to be based on predominant usage and is to be effected by means of appropriate type designation".

\section{Typification of the name, Nitraria komarovii}

When validating the name Bobrov (1946: 24) intentionally mentioned that $N$. komarovii "habitat in Turcomania occidental et in peninsula Apscheron" and stated the same twice (Bobrov, 1946: 28) while referring to the replaced synonym, N. schoberi var. polygama: “Описан по сборам Радме в Западной Туркмении. [Described from Radde’s collections in Western Turkmenia - Translated by N.K.]" and while giving the distribution of this species: "Установленная первоначально из окр. Красноводска (G. Radde, 1870) [Found originally near Krasnovodsk (G. Radde, 1870]". These two phrases are evidence that Bobrov meant $N$. schoberi var. polygama when he described N. komarovii. However, Bobrov politely mentioned also his predecessor: "В качестве типа ИАьиным избраны образцы Фрейна из Красноводска. Тип в Менинграде. [lyin has chosen as type Freyn's herbarium specimens from Krasnovodsk. Type in Leningrad. Translated by N.K.]". Bobrov does not discuss this phrase further and does not cite any specimens by Freyn. In his later works on the genus Nitraria Bobrov (1949: 198 and 1965: 1053) follows his earlier statement and intentionally refers to N. schoberi var. polygama as the replaced synonym.

Interestingly, Ilyin \& Lava (1944: 117) did not mention the variety $N$. schoberi var. polygama, although later Lava (1948: 54-57) cited N. schoberi var. polygama in the synonymy of $N$. komarovii, accepting the opinion of Bobrov published two years earlier (Bobrov 1946). When the taxonomic treatment for genus Nitraria was published by Bobrov in Flora of USSR (1949) and translated into English (1974), N. komarovii was accepted by Nikitin (1950) and is treated as a replacement name in IPNI (2019) and accepted as such in POWO (2019).

This name is also accepted by Tomoshevich et al. (2019a) and treated by them as a replacement name for $N$. schoberi var. polygama. Following a short history of the use of the name, N. komarovii, as described above, the predominant usage of the name was and is as a replacement name for N. schoberi var. polygama and thus following Art. 6.13 of the ICN (Turland et al. 2018) should be typified by the type of the replaced synonym (Art. 7.4 of ICN, Turland et al. 2018). Based on this, the lectotype is selected here from the material cited by Trautvetter as 'In Turcomania, prope Krasnowodsk (Radde)'.

At the Komarov botanical institute (LE) we found 8 herbarium sheets of Nitraria schoberi var. polygama Trautv., (LE00050757, LE00050758, LE00050759, LE00050760, LE00050761, LE00050762, LE00050763, LE00050764); all being syntypes (Art. 9.3 ICN) and we have chosen the specimen (LE00050757) as the lectotype (Fig. 1).

Nitraria komarovii Iljin \& Lava ex Bobrov Sovetskaya Botanica 14(1):28, 1946

三 Nitraria schoberi var. polygama Trautv. Trudy Imp. S.-Peterburgsk. Bot. Sada 1:25, 1871. - Nitraria komarovii Iljin \& Lava, Priroda 5-6:117, 1944, nom. inval.

Lectotype (designated here): - WESTERN TURKMENISTAN: Turcomania, Krasnowodsk, Juni [1870], Radde, 395/467 (LE00050757!). Figure 1.

Remaining syntypes: WESTERN TURKMENISTAN: Turcomania, Krasnowodsk, Junio 1870, Leg. D. Radde, 396/468, 397/469. Herbarium Trautvetter, (LE 00050758!); Turcomania, Krasnowodsk, Juni [1870], Radde, 467, ob...464 , (LE 00050759!); Krasnowodsk, Juni [1870], Radde, 396/468, 394/469. and label Turcomania, Krasnowodsk, im Junio 1870, Leg. D. Radde, 396/468, 397/469. Herbarium Trautvetter (LE 00050760!); Krasnowodsk, Radde, 468, 469, (LE 00050761!); Krasnowodsk, Juni [18]70, Radde, 464, (LE 00050762!); Turcomania, Krasnowodsk, Juni, Radde, 392/464, Herbarium Trautvetter (LE 00050763!); Turcomania, Krasnowodsk, im Junio 1870, Leg. D. Radde, 396/468, 397/469. Herbarium Trautvetter (LE 00050764!).

Note: One of the syntypes preserved at LE (LE00050757), was annotated by V.P. Botschantzev in 1960 as type of Nitraria komarovii (Fig. 1): “Тип - растения Рацде, т.к. они [по]служили Траутветтеру Аля описания подвида, а не растения Фрейна, как это утвержАает Ильин (Природа 5-6, 1944, 117), потому что здесь виА приведен без матинского описания, опр. Бочанцев 13.01.1960.” [Туре plants of Radde, because they have served Trautvetter in description of the variation, but not the plants of Freyn, as claimed by Ilyin (Priroda, 5-6, 1944: 117) since here the species are given without Latin description, det. Botschantzev, 13.01.1960. - translated by N.K.]. Since this has not been formally published, we designated the corresponding specimen as the lectotype here.

\section{Distribution}

Distribution of $N$. komarovii according to the literature (Bobrov 1946, 1949): Maritime saline clayey and sandyclayey deserts. - Caucasus: (Apsheron near Balakhany); Central Asia: Kara-Kum, West Turkmenistan in the area adjacent to Krasnovodsk Gulf (= Turkmenbashy), Cheleken. Endemic. During field trips in 2012-2015 by E. Banaev and M. Tomoshevich N. komarovii and N. schoberi plants were studied and specimens collected in Kazakhstan on the shores of lake Balkhash. Herbarium specimens deposited at the Central Siberian Botanical garden SB RAS and visible on-line in GBIF (Tomoshevich et al. 2019b). N. komarovii is close to N. schoberi, but this species differs by habit, shape and color of leaf blade, color of drupe and fruit sap (Tomoshevich et al. 2019a). 


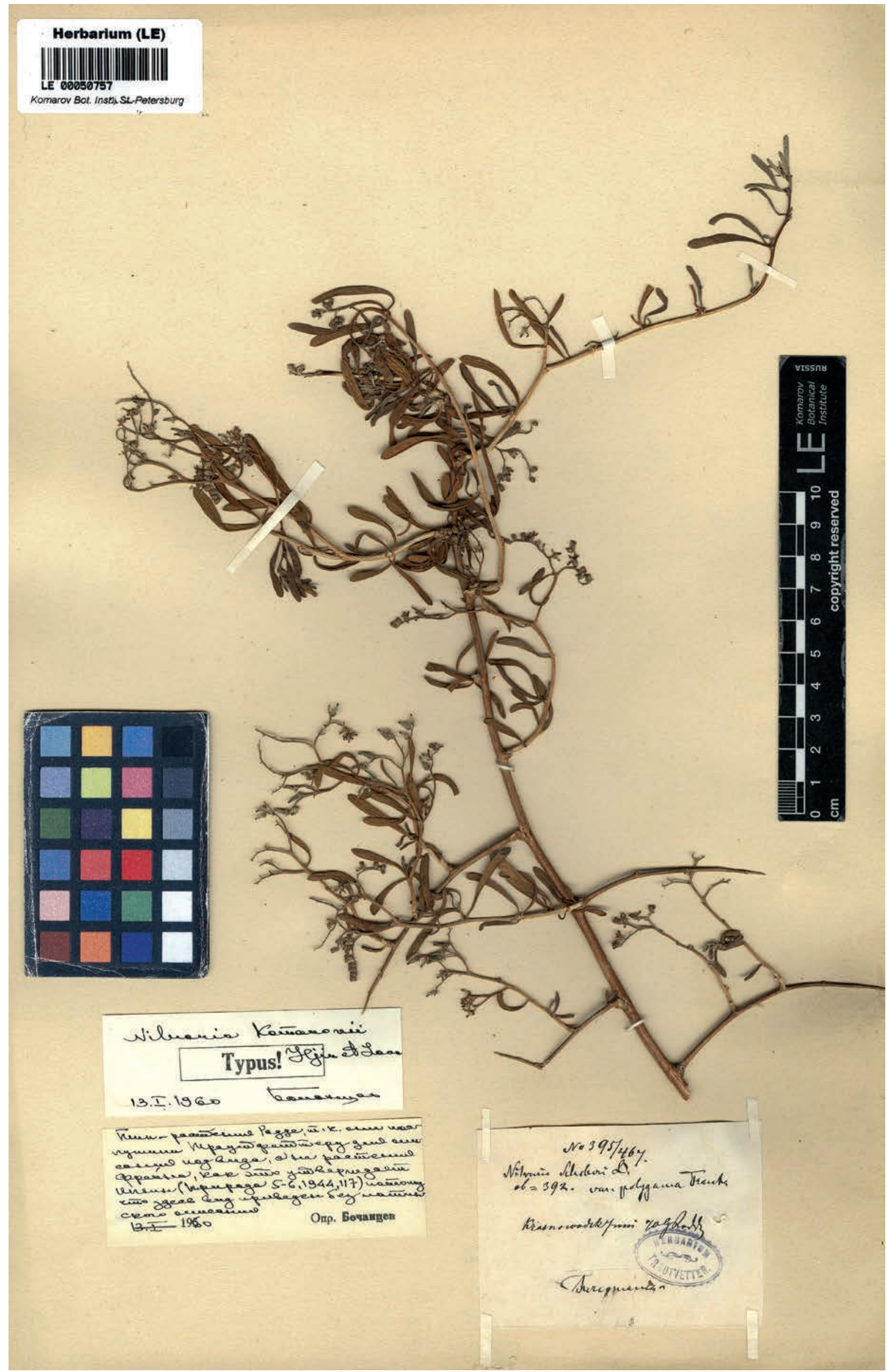

Figure 1 Lectotype of Nitraria komarovii Iljin \& Lava ex Bobrov (LE00050757) 


\section{ACKNOWLEDGEMENTS}

The authors are thankful to curators of the Herbarium collections of the Komarov Botanical Institute of RAS (LE), especially to Dr. Larisa M. Raenko for digitization and providing scans of Nitraria herbarium specimens and staff of the research group USU 440537 Herbarium CSBG (NS, NSK) for the scanning specimens and creation the Digital Herbarium CSBG (http://herb.csbg.nsc.ru:8081). We thank Dr. Irina Belyaeva (Royal Botanical Gardens, Kew) for her useful advice on the manuscript and Dr. Keith Chamberlain for linguistic.

\section{LITERATURE CITED}

Banaev, E.V., M.S. Voronkova, G.I. Vysochina \& M.A. Tomoshevich, 2015. Population structure and differentiation of the Siberian representatives of the genus Nitraria L. (Nitrariaceae) based on the composition and content of phenolic compounds in leaves. Contemporary Problems of Ecology 8(6):735-742.

Bobrov, E.G. 1946. About Asian species of the genus Nitraria. Sovetskaya Botanika 14(1):28 (in Russian). [Бобров Е.Г. 1946. Об азиатских видах рода Nitraria // Советская ботаника. Т. 14, № 1. С. 28].

Bobrov, E.G. 1949. Nitraria. In: Flora of the USSR, vol. 14 (B.K. Schidchkin, ed.), pp. 196-198, Izdatel'stvo AN SSSR, Moskva, Leningrad (in Russian). [Бобров Е.Г. 1949. Nitraria // Фмора СССР, т. 14 / поА реА. Б.К. Шишкина М.; А.: ИзА-во АН СССР. С. 196-198].

Bobrov, E.G. 1965. Origin of desert flora of the Old World related to review of the genus Nitraria L. Botanicheskii Zhurnal 50(8):1053-1067 (in Russian). [О происхождении фморы пустынь старого света в связи с обзором poдa Nitraria L. // Ботанический журнац. T. 50, № 8. C. 1053-1067].

Bobrov, E.G. (1974) Nitraria. In: Flora of the USSR, vol. 14. Translated from Russian (B.K. Schidchkin, ed.), pp. 150 152, Jerasulem.

Iljin, M.M. 1944. Nitraria and the origin of the deserts flora. Priroda 5-6:117 (in Russian). [ИАьин M.M. 1944. Nitraria и происхождение флоры пустынь // Природа. № 5-6:117].

IPNI (2019) International Plant Names Index, https://beta. ipni.org/ Last accessed: 6 October 2019.

Lava, Y.I. 1948. The genus Nitraria L. in Turkmenistan. Izvestiva Turkmenskogo Filiala Akademii Nauk SSSR 1:54 57 (in Russian). [РоА Nitraria L. в Туркменистане / / Известия Туркменского филиала Академии наук СССР. T. 1. C. 54-57].

Linnaeus, C. 1759. Systema Naturae ed. 10, vol. 2. Laurentii Salvii, Holmiae, Stockholm, 1384 pp.

Nikitin, V.V. 1950. Zygophyllaceae. In: Flora Turkmenii, vol. 5. (B.K. Shishkin, ed.), pp. 20-35 Turkmenskoe gosudar- stvennoe Izd., Ashkhabad (in Russian). [Никитин B.B. 1950. Zygophyllaceae // Фцора Туркмении. Ашхабад: Туркменское государственное издательство. Т. 5. С. 20-35].

POWO (2019) Plants of the World Online. Facilitated by the Royal Botanic Gardens, Kew. Available from: http:// www.plantsoftheworldonline.org. Last accessed: 6 October 2019.

The Angiosperm Phylogeny Group, M.W. Chase, M.J.M. Christenhusz, M.F. Fay, J.W. Byng, W.S. Judd, D.E. Soltis, D.J. Mabberley, A.N. Sennikov, P.S. Soltis \& P.F. Stevens. 2016. An update of the Angiosperm Phylogeny Group classification for the orders and families of flowering plants: APG IV. Botanical Journal of the Linnean Society 181(1): 1-20.

Thiers, B. 2019. [Continuously updated] Index Herbariorum: A global directory of public herbaria and associated staff. New York Botanical Garden's Virtual Herbarium. Available from: http://sweetgum.nybg.org/science/ih/ Last accessed 20 May 2019.

Tomoshevich, M., E. Banaev \& A. Ak-Lama 2019a. Nitraria komarovii Iljin \& Lava ex Bobrov (Nitrariaceae), a new record for the flora of Kazakhstan. Check List 15(5):891-897.

Tomoshevich, M., E. Banaev, T. Ak-Lama, N. Kovtonyuk \& I. Han 2019b. Nitraria komarovii in the Digital herbarium of CSBG SB RAS (NSK). Version 1.2. Central Siberian Botanical Garden SB RAS. Occurrence dataset https:// doi.org/10.15468/jp2qco. Last accessed via GBIF.org on 05 October 2019.

Trautvetter, E.R. 1871. Observations in plantas a Dre. G. Radde anno 1870 in Turcomania et Transcaucasia lectas. Trudy Imperatorskago S.-Peterburgskago Botanicheskago Sada 1: 25. Available at https://archive.org/details/ mobot31753002529961.

Turland, N.J., J.H. Wiersema, F.R. Barrie, W. Greuter, D.L. Hawksworth, P.S. Herendeen, S. Knapp, W.-H Kusber, D.-Z. Li, K. Marhold, T.W. May, J. McNeill, A.M. Monro, J. Prado, M.J. Price \& G.F. Smith (eds) 2018. International Code of Nomenclature for algae, fungi, and plants (Shenzhen Code) adopted by the Nineteenth International Botanical Congress Shenzhen, China, July 2017. Regnum Vegetabile 159. Koeltz Botanical Books, Glashütten, 254 pp. Available at https://doi.org/10.12705/Code.2018.

Voronkova, M.S., M.A. Tomoshevich \& E.V. Banaev 2017. Comparative study of phenolic compounds composition and content in leaves of the genus Nitraria (Nitrariaceae) plants). Khimiya Rastitelnogo Syr'ya 4:107-116 (in Russian). [Воронкова М.С., Томошевич М.А., Банаев Е.В. 2017. Сравнительное изучение состава и содержания фенольных соединений Аистьев растений рода Nitraria (Nitrariaceae) // Химия растительного сырья. T. 4. C. 107-116].

Wilson, K.L. 1992. Nitraria. In: Flora of New South Wales, vol. 3 (G.J. Harden, ed.), p. 14, New South Wales University Press, New South Wales, Australia. 